American Journal of Pharmaceutical Education 2019; 83 (9) Article 7761.

\title{
COMMENTARY
}

\section{Before We Talk About Student Debt Cancelation, Can We Talk About Interest Rates?}

\author{
T. Joseph Mattingly II, PharmD, MBA, PhD \\ University of Maryland School of Pharmacy, Baltimore, Maryland \\ Editorial Board Member, American Journal of Pharmaceutical Education, Arlington, Virginia
}

Submitted by July 17, 2019; accepted August 6, 2019; published November 2019.

\begin{abstract}
Recently, several presidential candidates in the Democratic primary have created media buzz with policy proposals to eliminate debt (either partially, or completely) for millions of Americans. ${ }^{1}$ Given the rise in tuition prices and growing debt for pharmacy graduates over the past decade, these proposals may offer hope for those still drowning in debt and potentially resentment for others who sacrificed making other investments to pay down student loans. ${ }^{2-4}$ While bold policy proposals help make great sound bites and campaign ads, they may also divert attention from more pragmatic solutions where a larger majority of people with different political biases could come to consensus. This commentary focuses less on flashy political rhetoric and more on a boring aspect of student loans: the mathematical components of debt. Using the Class of 2017 exiting survey data published by the American Association of Colleges of Pharmacy (AACP) Office of Institutional Research \& Effectiveness, ${ }^{5}$ this article aims to demonstrate how more moderate steps to reduce interest rates may offer relief for pharmacy graduates while avoiding potential resentment and other unintended consequences. ${ }^{4}$
\end{abstract}

Keywords: tuition; student debt; finance; interest rates

Debt should always be described as a function of its parts. In general, a loan consists of the principal, term, and interest rate. The principal refers to the amount of money borrowed. The term describes the length or life of the loan. For student loans, typical repayment terms are 10 and 25 years. The interest rate is the financial cost of the debt (it is not the total cost of the debt, but that topic requires its own in-depth discussion on cost of capital, opportunity costs, and other economic and finance principles). For Doctor of Pharmacy (PharmD) students, focusing on the impact of interest rates on monthly payments and the total term (amortization) for their student loans may be the most beneficial approach to helping achieve personal finance goals.

The loan principal refers to the amount owed by the borrower to the lender. This article does not address the issues related to the cost of college or factors that have led to the larger beginning principal amounts students are

Corresponding Author: Joey Mattingly, University of Maryland School of Pharmacy, 20 N. Pine Street, N415, Baltimore, Maryland 21201. Tel: 410-706-8068. Email: jmattingly@rx.umaryland.edu.

Conflicts of Interest: The author and the author's spouse currently have student debt related to both undergraduate and professional school expenses and both are employed at the University of Maryland School of Pharmacy. facing after graduation, as those have been described elsewhere. ${ }^{6,7}$ However, any policies or initiatives to lower the total amount students have to borrow would certainly have an impact on the financial situation of future graduates. One principal-related issue that rarely is discussed pertains to the additional origination fee charged at the time the loan is dispersed that ranges from $1 \%-4.2 \%$ and is built into the beginning principal amount. ${ }^{8}$

The term refers to the length of time within which the borrower agrees to pay back the full principal and interest owed. Unlike mortgages or other common loans, the term for a student loan is not determined at the time of origination but rather at the time the student or graduate selects a repayment plan. Depending on the plan selected after graduation, the borrower may have a standard repayment from 10 to 30 years, with the extended repayment plan set at 25 years. 9

The interest rate is described by the US Department of Education as the "cost" of borrowing money that is paid from the borrower to the lender (in addition to the aforementioned). ${ }^{8}$ For federal student loans, these rates are determined annually and are fixed for the full term of the loan. Over the past eight years, rates have ranged from as low as $3.4 \%$ to as high as $8.5 \%$ depending on the year the rate was set and the type of loan (Direct Subsidized, Direct Unsubsidized, or Direct PLUS). ${ }^{8}$ 


\section{American Journal of Pharmaceutical Education 2019; 83 (9) Article 7761.}

When a borrower signs an agreement to pay back $\$ 100,000$ at an interest rate of 5\%, the initial thought for a financial novice may be that the cost of the loan would simply be $5 \%$ of the total money borrowed (in this case $\$ 5,000)$. Anyone who has experience borrowing money would know that the actual cost to borrow $\$ 100,000$ will likely be much more than $\$ 5,000$ once you factor in the term the borrower has to repay the debt. The term component of the debt and frequency or number of payments over the term are critical components in determining the total cost of the loan. This is because the interest owed on every payment is a function of the ending balance of the principal, creating a scenario where the interest owed on each payment actually decreases over the life of the loan. In order to keep the routine (typically monthly) payments consistent, a loan repayment typically follows an amortization schedule. ${ }^{10}$ In the context of student debt, amortization refers to the distribution of loan payments (including both principal and interest) over the term of the loan with the payment amounts determined by a relatively simple formula (Equation 1). While straightforward, this mathematical formula may be one of the biggest challenges graduates face as they attempt to conquer significant student debt.

$$
\begin{aligned}
& \text { Monthly Payment Amount } \\
& =\frac{\text { Principal } * \text { Interest Rate }}{12\left[1-\left(1+\frac{\text { Interest Rate }}{12}\right)^{-12 * \text { Term }}\right]}
\end{aligned}
$$

\section{Case Example: PharmD Class of 2017 Interest Rate Reduction vs Debt Cancelation}

Using the self-reported debt statistics from the 2017 AACP Graduating Student Survey, the mean principal loan at graduation answered by the $86 \%$ of students who reported borrowing money to pay for college was $\$ 163,494 .^{5}$ If we assume that $86 \%$ number holds for all graduates and extrapolate to those who did not respond to the survey, then we can estimate just over $\$ 2 \mathrm{~B}$ in total student debt for 12,466 students. Using the 10-year fixed standard repayment plan and 25-year fixed extended repayment plan, we can further estimate monthly payments per student and total interest paid over the full term at varying interest rates (Table 1). In this example, interest rates of $6 \%$ (current graduate debt average rates), 3\% (lowest rate in current environment, and 1.5\% (hypothetical rate half of lowest rates) were used to demonstrate the total costs of debt at each level.

For pharmacy graduates alone, eliminating all student debt for one single graduating class would cost more than \$2B. Assuming that all loan servicers currently "break-even" at the $6 \%$ interest rate, the total gross margin that lenders would capture over 10- and 25-year repayment plans would be $\$ 677 \mathrm{M}$ and $\$ 1.9 \mathrm{~B}$, respectively. This means reducing the rates to 3\% would "cost" $\$ 353 \mathrm{M}$ (the difference between revenue at $6 \%$ and $3 \%$ ) over 10 years, or just $\$ 35.3 \mathrm{M} /$ year. Reducing the rates all the way to the level of inflation at $1.5 \%$ would cost $\$ 519 \mathrm{M}$ over 10 years, or just $\$ 51.9 \mathrm{M} /$ year. In other words, substantially lowering interest rates to $3 \%$ or $1.5 \%$ would cost the government a fraction of what total debt cancelation for pharmacy students in the Class of 2017 would cost.

When it comes to making "progress" in reducing the principal balance, the term and interest rates can have a major impact. At an interest rate of $6 \%$ and extended repayment term, the average student will be paying $\$ 1,053$ / month and will only see about a $10 \%$ reduction in

Table 1. Estimated Debt Characteristics at Varying Interest Rate Levels for Class of 2017 Doctor of Pharmacy Graduates $(\mathrm{N}=12,466)$

\begin{tabular}{llll}
\hline & \multicolumn{3}{c}{ Interest Rates Levels } \\
\cline { 2 - 4 } Loan Characteristic & \multicolumn{1}{c}{$\mathbf{6 \%}$} & \multicolumn{1}{c}{$\mathbf{3 \%}$} & $\mathbf{1 . 5 \%}$ \\
\hline Beginning Principal & & $\$ 2,038 \mathrm{M}$ & $\$ 2,038 \mathrm{M}$ \\
& & & \\
10-year term (Standard Repayment) & $\$ 677 \mathrm{M}$ & $\$ 324 \mathrm{M}$ & $\$ 158 \mathrm{M}$ \\
$\quad$ Total Interest Paid at Full Term & $\$ 1,815 / \mathrm{month}$ & $\$ 1,579 / \mathrm{month}$ & $\$ 1,468 /$ month \\
$\quad$ Monthly Payment Per Student & $\$ 1,170 \mathrm{M}$ & $\$ 1,095 \mathrm{M}$ & $\$ 1,057 \mathrm{M}$ \\
Total Principal Remaining After 5 Years & $57.4 \%$ & $53.7 \%$ & $51.9 \%$ \\
\% of Principal Remaining After 5 Years & & & $\$ 407 \mathrm{M}$ \\
& & $\$ 861 \mathrm{M}$ & $\$ 654 / \mathrm{month}$ \\
25-year term (Extended Repayment) & $\$ 1,901 \mathrm{M}$ & $\$ 775 / \mathrm{month}$ & $\$ 1,689 \mathrm{M}$ \\
$\quad$ Total Interest Paid at Full Term & $\$ 1,053 / \mathrm{month}$ & $\$ 1,743 \mathrm{M}$ & $82.9 \%$ \\
$\quad$ Monthly Payment Per Student & $\$ 1,833 \mathrm{M}$ & $85.5 \%$ & \\
Total Principal Remaining After 5 Years & $89.9 \%$ & & \\
\% of Principal Remaining After 5 Years & & & \\
\hline
\end{tabular}

Abbreviations: $\mathrm{M}=$ million 


\section{American Journal of Pharmaceutical Education 2019; 83 (9) Article 7761.}

principal after 5 years of routine payments (Table 1). Members of the Class of 2017 on this extended repayment plan can expect to have approximately $75 \%$ of their original principal balance when they receive an invitation to their 10-year pharmacy school reunion (Figure 1). This may cause some concern regarding the long-term impact of student debt on pharmacy school foundation fundraising and other alumni engagement activities. Decreasing student loan interest rates to inflation $(\sim 1.5 \%)$ levels could reduce monthly payments, thereby freeing up discretionary income and allowing students to see more progress in reducing the principal balance.

\section{Non-Pecuniary Reasons to Support Lower Rates over Debt Cancelation}

One potential unintended consequence of debt cancelation may relate to the feelings of resentment generated between existing graduates that make up the alumni base for schools. ${ }^{4}$ For graduates who sacrificed various luxuries (leisure travel, conspicuous consumption, etc) in order to commit large proportions of discretionary income toward student loan principal payments, a sense of unfairness would likely arise. While these feelings may be mixed for many, it would be reasonable for those graduates to feel punished for actions that should be applauded.
As with most policy changes with financial implications, debt cancelation would shift incentives. In this case, current and future students may be inclined to borrow larger sums or take the maximum amounts rather than borrowing only the minimum required to cover tuition and costs of living. This may also slow down the work that some universities and organizations are doing to reduce the cost of college and become more efficient.

The mere discussion of debt cancelation may create an issue with present borrowers considering where to spend existing discretionary dollars. My wife and I currently have significant student debt balances from our undergraduate and professional school education. We also have long-term debt in the form of a mortgage for our home (which, has a lower interest rate than our existing student loans). Over the next 18-24 months, while this national policy debate and presidential election occurs, we are unsure whether it would be better to spend our discretionary dollars on paying off the student loans or the mortgage. Even though the mortgage has a lower interest rate, one could argue that the potential for student debt cancelation in 2020 is incentivizing us to simply pay the minimum on our student loans.

While debt forgiveness remains a priority issue for some voters, there is overwhelming public support

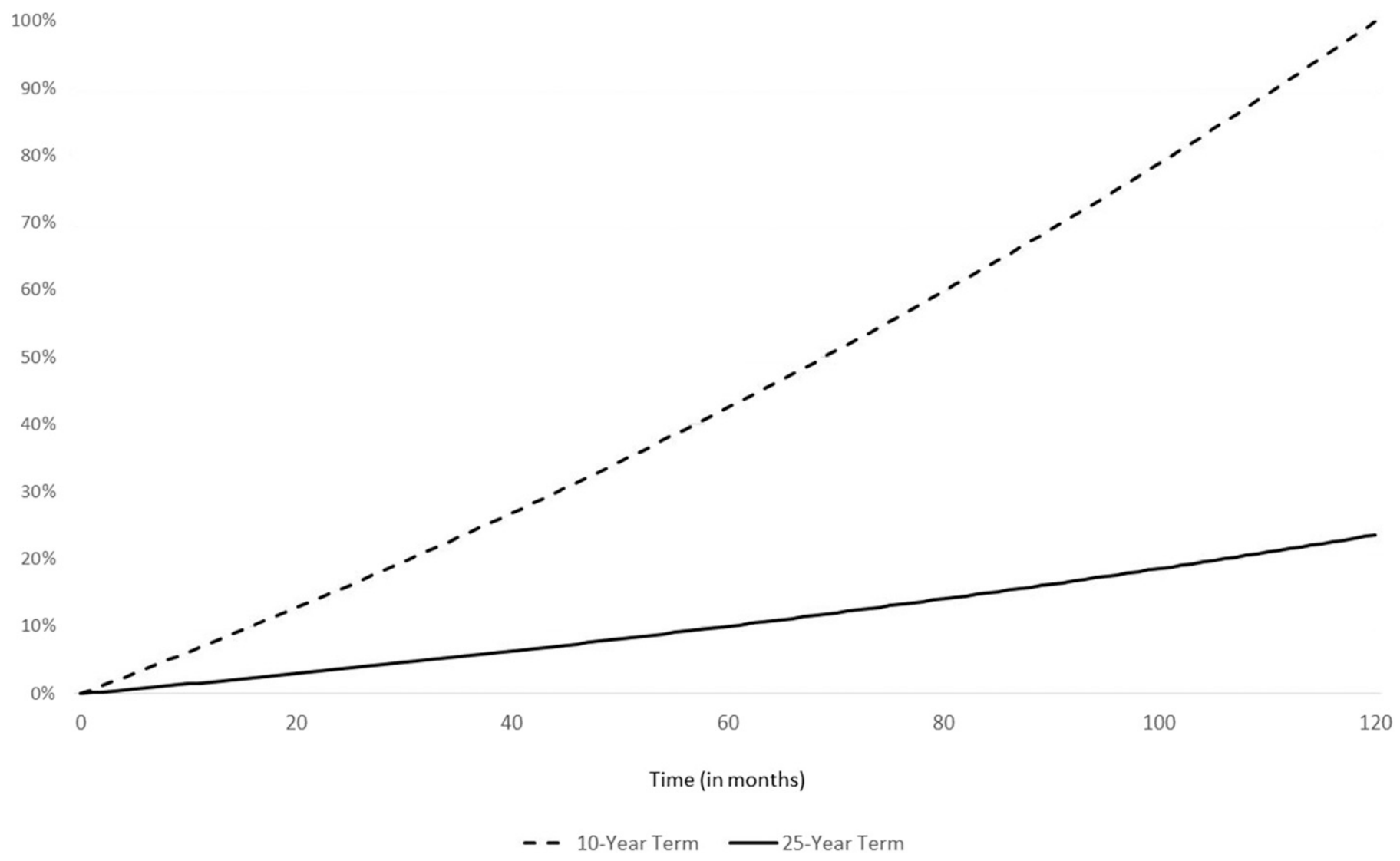

Figure 1. Cumulative Percentage of Principal Paid by Month over 10 years (120 months) for 10- and 25-year Terms 


\section{American Journal of Pharmaceutical Education 2019; 83 (9) Article 7761.}

for lower interest rates and increased grant funding for costs associated with college. ${ }^{11}$ Even more surprisingly, non-Millennial voters are stronger supporters of lower interest rates than their Millennial counterparts. ${ }^{11}$ While debt forgiveness can be extremely divisive politically, most can support bipartisan efforts to reduce interest rates for student loans. Lowering interest rates can still create incentive alignment issues as it would make student debt more favorable compared to other types of debt, but the debt would still remain as a disincentive.

\section{CONCLUSION}

The debate around student debt, especially for pharmacy educators, is complex and includes a wide range of objective and subjective factors. ${ }^{7}$ As with any topic discussed within campaigns during major election years, support for or against policy proposals that significantly change the way post-secondary education is financed in the United States will likely fall along political party lines. However, the math behind the debt itself should not be partisan. It is just math. As a graduate with student debt and an educator employed by a school currently creating more graduates with student debt, I hope we can put down our red and blue hats long enough to build consensus around a pragmatic solution to a growing problem.

\section{REFERENCES}

1. Lombardo C. Student debt forgiveness sounds good. What might happen if the government did it? NPR. https://www.npr.org/2019/07/ 10/738506646/student-debt-forgiveness-sounds-good-what-mighthappen-if-the-government-did-it. Published July 10, 2019. Accessed July 13, 2019.
2. Mattingly II TJ, Ulbrich TR. Evaluating the changing financial burdens for graduating pharmacists. Am J Pharm Educ. 2017;81(7):Article 5990. doi:10.5688/ajpe8175990.

3. Chisholm-Burns MA, Spivey CA, Stallworth S, Zivin JG. Educational debt crisis: analysis of debt and income among pharmacists, physicians, dentists, optometrists, and veterinarians. Am J Pharm Educ. 2019;83(9):Article 7460.

4. Emba C. Student debt vs. the politics of resentment. The Washington Post. https://www.washingtonpost.com/opinions/ elizabeth-warrens-debt-relief-plan-could-counteract-our-politics-ofresentment/2019/04/26/bfe9718e-683a-11e9-a1b6b29b90efa879_story.html?utm_term $=. e 6 a 517 \mathrm{cce} 3 \mathrm{e} 2$. Published April 26, 2019.

5. American Association of Colleges of Pharmacy. American Association of Colleges of Pharmacy Graduating Student Survey: 2017 National Summary Report. Published 2017. https:// www.aacp.org/categories/graduating-student. Accessed July 9, 2019. 6. Mattingly II TJ. Is there room for efficiency in pharmacy education? Am J Pharm Educ. 2018;82(9):Article 7271. doi:10.5688/ ajpe8297271.

7. Cain J, Campbell T, Congdon B, et al. Complex issues affecting student pharmacist debt. Am J Pharm Educ. 2014;78(7):Article 131. 8. US Department of Education. Understand how interest is calculated and what fees are associated with your federal student loan. https://studentaid.ed.gov/sa/types/loans/interest-rates\#olderrates. Published 2019. Accessed July 13, 2019.

9. US Department of Education. Choose the federal student loan repayment plan that's best for you. https://studentaid.ed.gov/sa/ repay-loans/understand/plans. Published 2019. Accessed July 13, 2019.

10. Kagan J. Amortized Loan Definition. Investopedia. https:// www.investopedia.com/terms/a/amortized_loan.asp. Published 2019. Accessed July 13, 2019.

11. Newall, M. Chen, E. Voters keen on lowering student debt through greater federal funding. Ipsos. https:/www.ipsos.com/en-us/ news-polls/voters-keen-on-lowering-student-debt. Published May 23, 2019. Accessed July 14, 2019. 